\title{
Tongue in the Eye: Ocular Secretions of a Green Iguana (Iguana iguana) Lapped by a Hairy-legged Bee (Centris sp.)
}

Ivan Sazima $^{1}$, Marlies Sazima ${ }^{2}$, and Mardiore Pinheiro ${ }^{3}$

\begin{abstract}
${ }^{1}$ Museu de Zoologia, Caixa Postal 6109, Universidade Estadual de Campinas, 13083-970 Campinas, São Paulo, Brazil (isazima@gmail.com) ${ }_{2}^{2}$ Departamento de Biologia Vegetal, Instituto de Biologia, Universidade Estadual de Campinas, 13083-970, Campinas, SP, Brazil (msazima@unicamp.br) ${ }^{3}$ Programa de Pós-Graduação em Ambiente e Tecnologias Sustentáveis, Universidade Federal da Fronteira Sul, 97900-000, Cerro Largo, RS, Brazil (mardiore.santos@uffs.edu.br)
\end{abstract}

$\mathrm{I}^{\mathrm{n}}$ $n$ the Neotropics (Costa Rica and Ecuador), eye secretions of the Yellow-spotted River Turtle (Podocnemis unifilis) and the Spectacled Caiman (Caiman crocodilus) are lapped by Hairy-legged Bees (Centris spp.), which reach the eye while hovering (Dangles and Casas 2012; de la Rosa 2014). In the Palaeotropics (Thailand), the ocular secretions of the Yellow Tortoise (Indotestudo elongata) are lapped by the stingless bees, Lisotrigona cacciae and L. furva, that alight and settle under the eye (Bänziger and Bänziger 2010). This behavior has been named tear-drinking, tear-feeding, or lachryphagy and is believed to supply the bees with essential nutrients, such as sodium and potassium, along with protein (Bänziger and Bänziger 2010; Dangles and Casas 2012; de la Rosa 2014).

Tear-feeding by bees appears to be unrecorded for reptiles other than chelonians and crocodilians. Herein we report on a lizard, the Green Iguana (Iguana iguana), whose eye secretions were lapped by a Hairy-legged Bee (Centris sp.) in the Brazilian Amazon. Iguana iguana is a large, mostly herbivorous iguanid lizard that is widely distributed in Brazil, where is lives in biomes as diverse as the humid Amazonian rainforest and the semi-arid Caatinga (Avila-Pires 1995). Iguanas often are found near water and climb trees, where they may forage, rest, and thermoregulate (Avila-Pires 1995; Burghardt and Rand 1982). The hairy-legged bees of the Centridini (Apidae) are renowned for visiting specialized flowers to collect oil that, when mixed mostly with pollen, serves as larval food (Vogel 1974; Alves-dos-Santos et al. 2007). Centridine bees are important pollinators of several plant species, including crops (Gaglianone et al. 2010). As well as nectar, another liquid collected by Centris spp. seems to be the ocular secretions of reptiles (Dangles and Casas 2012; de la Rosa 2014).

At about 1100 h on 6 August 2019, we observed a Green Iguana (about $100 \mathrm{~cm}$ total length) on a sandy beach at Ponta do Toronó, near the Arapiuns River $\left(2.3350^{\circ} \mathrm{S}, 55.1100^{\circ} \mathrm{W}\right)$, Pará State, in northern Brazil. The lizard was on waterlogged sand in the shallows, apparently thermoregulating. A large female Hairy-legged Bee hovered near the iguana's head and, from time to time, lapped the lizard's eye secretions (Fig. 1). While lapping tears, the bee inserted its mouthparts beneath the iguana's eyelids and was able to do so only while the reptile kept its eyes open or left a slit. The iguana seemed somewhat disturbed by the bee's visits, as it kept the eye closed when the hovering bee approached (Fig. 2) or actually touched the eye. The interaction between the lizard and the bee lasted about 7-8 min with visits to both eyes, although the right one received more attention.

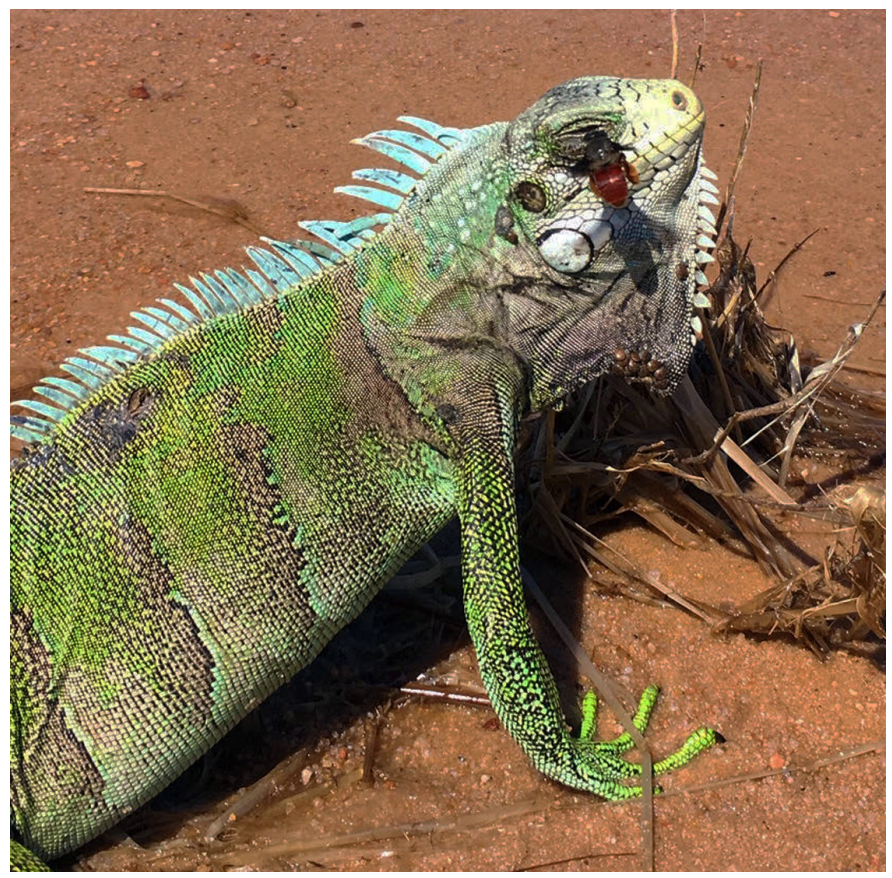

Fig. 1. A Green Iguana (Iguana iguana) on waterlogged sand while a Hairy-legged Bee (Centris sp.) laps the lizard's ocular secretions through an eye slit. Photograph by Mardiore Pinheiro. 


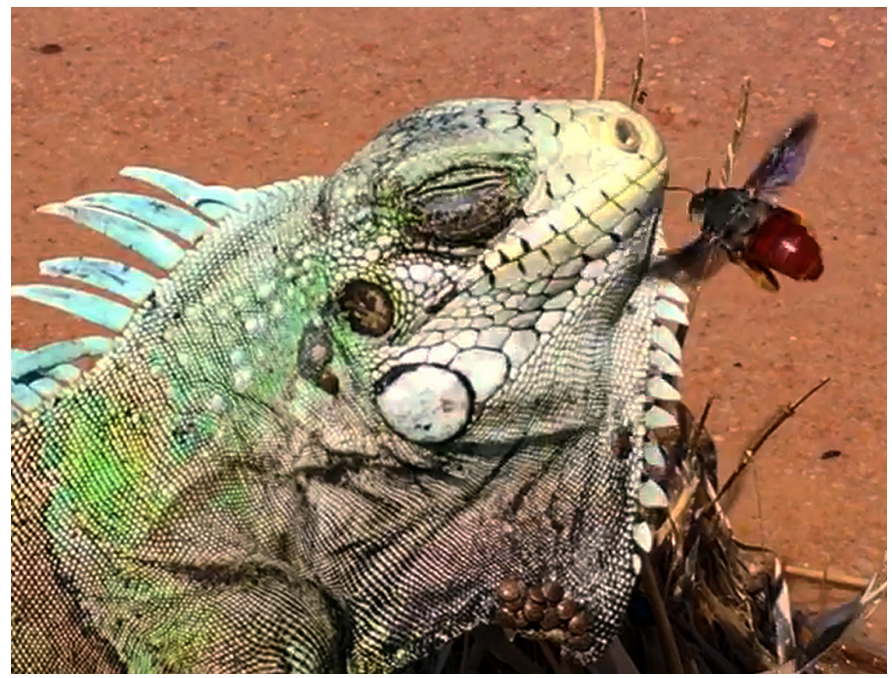

Fig. 2. A Green Iguana (Iguana iguana) closes its eyes when a Hairy-legged Bee (Centris sp.) hovers nearby. Note the clump of ticks at the edge of the lizard's dewlap. Photograph by Mardiore Pinheiro.

As the lizard was likely thermoregulating or resting on the sandy shore, we considered the presence of the Hairy-legged Bee as a nuisance that disturbed the iguana, even if only slightly, and this disruption could affect the lizard's activity (Burghardt and Rand 1982). A somewhat greater disruption by Centris sp. was recorded for a basking Yellow-spotted River Turtle, Podocnemis unifilis (Rainforest Expeditions 2013), which also closed its eyes and even moved its forelimbs to drive the bee off. We note herein that all interactions between Centris spp. bees and the three reptilian groups (namely turtles, crocodilians, and lizards) occurred at open sites on riverbanks (Dangles and Casas 2012; de la Rosa 2014; present paper). We agree with de la Rosa (2014) that interactions between Centris spp. bees and other crocodilian and chelonian species will be recorded. We also suggest that additional instances of lizard and Hairy-legged Bee interactions in Brazil could involve large semiaquatic teiids such as the Northern Caiman Lizard (Dracaena guianensis) and the Crocodile Tegu (Crocodilurus amazonicus'), which occur in

${ }^{1}$ This species traditionally has been assigned to Crocodilurus lacertinus but see de Massary and Hoogmoed (2001). the Amazonia, and the Paraguay Caiman Lizard (D. paraguayensis) that lives in the Pantanal (Avila-Pires 1995; Mesquita et al. 2016). These interactions would likely occur while these lizards bask or rest on branches near riverbanks (Avila-Pires 1995; Avila et al. 2014; Mesquita et al. 2016).

\section{Acknowledgements}

We thank AJ Gutman for insightful comments and Lucas Rodrigues Piovesan for help with the photographs. IS also thanks CNPq (Conselho Nacional de Desenvolvimento Científico e Tecnológico) for past grants that allowed studies of vertebrate natural history (00992/79-ZO); MS thanks CNPq (grant 302781/2016-1).

\section{Literature Cited}

Alves-dos-Santos, I., I.C. Machado, and M.C. Gaglianone. 2007. História natural das abelhas coletoras de óleo. Oecologia Brasiliensis 11: 544-557.

Avila, I., F. Bauer, E. Boungermini, and N. Martínez. 2016. Dracaena paraguayensis: aportes sobre el conocimiento de su biología, ecología y distribución. Kempffiana 12: 122-130.

Avila-Pires, T.C.S. 1995. Lizards of Brazilian Amazonia. Zoologische Verhandelingen, Leiden 299: 1-706.

Bänziger, H. and S. Bänziger. 2010. Mammals, birds and reptiles as hosts of Lisotrigona bees, the tear drinkers with the broadest host range (Hymenoptera, Apidae). Mitteilungen der Schweizerischen Entomologischen Gesellschaft 83: 271-282.

Burghardt, G.M. and S.A. Rand (eds.). 1982. Iguanas of the World, Their Behavior, Ecology and Conservation. Noyes Publications, Park Ridge, New Jersey.

Dangles, O. and J. Casas. 2012. The bee and the turtle: a fable from Yasuní National Park. Frontiers in Ecology 10: 446-447.

Gaglianone, M.C, H.H.S. Rocha, C.R. Benevides, C.M. Junqueira, and S.C. Augusto. 2010. Importância de Centridini (Apidae) na polinização de plantas de interesse agrícola: o maracujá-doce (Passiflora alata Curtis) como estudo de caso na regiāo sudeste do Brasil. Oecologia Australis 14: 152-164.

Massary, J.-C. de and M.S. Hoogmoed. 2001. Crocodilurus amazonicus Spix, 1825: The valid name for Crocodilurus lacertinus auctorum (nec Daudin, 1802) (Squamata: Teiidae). Journal of Herpetology 35: 353-357.

Mesquita, D.O., G.R. Colli, G.C. Costa, F.G.R. França, A.A. Garda, and A.K Péres, Jr. 2006. At the water's edge: Ecology of semiaquatic teiids in Brazilian Amazon. Journal of Herpetology 40: 221-229.

Rainforest Expeditions. 2013. Bees drinking turtle tears. <http://www.perunature. com>.

Rosa, C.L. de la. 2014. Additional observations of lachryphagous butterflies and bees. Frontiers in Ecology 12: 210.

Vogel, S. 1974. Ölblumen und ölsammelnde Bienen. Tropische und subtropische Pflanzenwelt 7: 1-267. 